Simple approach to the synthesis of 3-fluoro pyrazolo[1,5-a]pyrimidine analogues

Hassen Bel Abed, Oscar Mammoliti, Guy Van Lommen and Piet Herdewijn
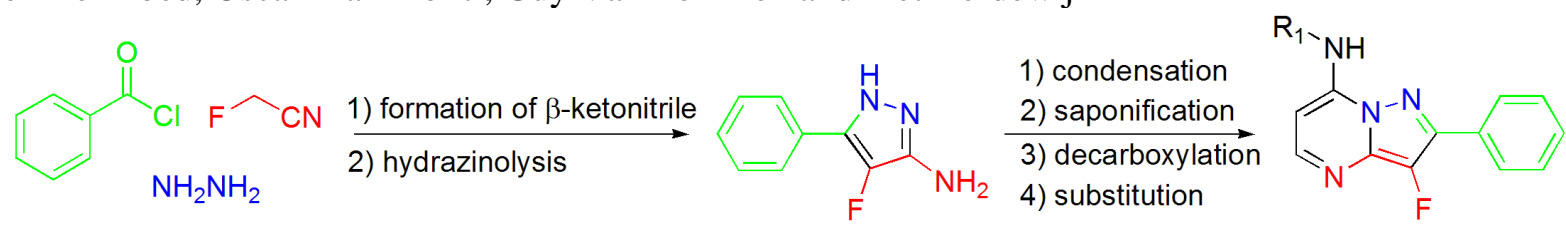

$\mathrm{R}_{1}=$ aliphatic amine, cycloalkyl amine, benzyl amine and heteroaryl amine 


\title{
Simple approach to the synthesis of 3-fluoro pyrazolo[1,5-a]pyrimidine analogues
}

\author{
Hassen Bel Abed ${ }^{\mathrm{a}}$, Oscar Mammoliti ${ }^{\mathrm{b}}$, Guy Van Lommen ${ }^{\mathrm{b}}$ and Piet Herdewijn ${ }^{\mathrm{a}^{*}}$ \\ ${ }^{a}$ Rega Institute for Medical Research, Laboratory of Medicinal Chemistry, Katholieke Universiteit Leuven, Minderbroedersstraat 10 , B-3000 Leuven, Belgium \\ ${ }^{b}$ Galapagos, Laboratory of Medicinal Chemistry, General de Wittelaan L11 A3, B-2800 Mechelen, Belgium
}

\begin{abstract}
Article history:

Received

Received in revised form

Accepted

A simple method for the synthesis of novel 3-fluoro pyrazolo[1,5-a]pyrimidine analogues has been developed starting from fluoro acetonitrile and benzoyl chloride. The desired compounds are synthesized from a 3-amino-4-fluoro pyrazole intermediate. The versatility of the approach was demonstrated by the synthesis of a small library of pyrazolo[1,5-a]pyrimidine.
\end{abstract}

Available online

Keywords:

Pyrazolo[1,5-a]pyrimidine

Pyrazole

Heterocycle

Cyclization
Pyrazolo[1,5-a]pyrimidine ${ }^{1}$ analogues have been extensively studied as kinase inhibitors and several compounds have been found active such as the B-Raf kinase inhibitor ${ }^{2} \mathbf{1}$ or the cyclin dependent kinase inhibitor $\mathbf{2}^{3}$ (Figure 1).

In addition, this core has shown inhibitory activity towards other kinases such as Pim. The substitution pattern and the kind of decoration explored, allowed selectivity towards particular kinases. It has been demonstrated that the pyrazolo[1,5a]pyrimidine scaffold itself interacts with the hinge region of the ATP binding site. ${ }^{4}$
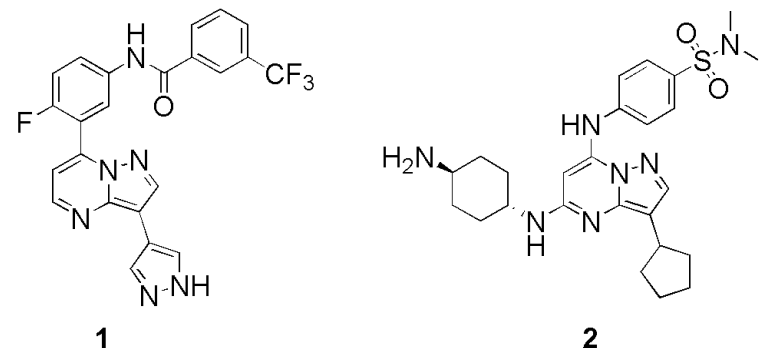

Figure 1. Kinase inhibitors based on pyrazolo[1,5-a]pyrimidine.

In view of previous literature ${ }^{5}$ describing this structure as potential scaffold to develop kinase inhibitor, the synthesis of 3fluoro pyrazolo[1,5-a]pyrimidine was considered. This synthesis fits in our ongoing interest ${ }^{6}$ to explore new heterocycles for drug design project.
Herein, we describe the synthesis of 3-fluoro pyrazolo[1,5a]pyrimidine starting from 3-amino-4-fluoro pyrazole. One of the most common methods for the synthesis of fluorinated pyrazolo[1,5-a]pyrimidine is the fluorination of the scaffold directly by electrophilic fluorination, ${ }^{7}$ using a reagent like 1chloromethyl-4-fluoro-1,4-diazoniabicyclo[2.2.2]octane bis(tetrafluoroborate) also known as Selectfluor $3^{8}$ (Scheme 1).

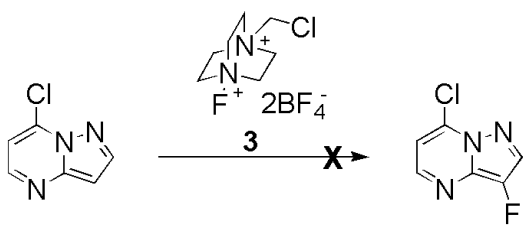

Scheme 1. Electrophilic fluorination of the 7-chloro pyrazolo[1,5a]pyrimidine.

However, such fluorination method is generally low yielding and has never worked in the case of the 7-chloro pyrazolo[1,5a]pyrimidine in our hands, in contrast to other halogenations such as iodination. ${ }^{9}$ An alternative procedure was envisioned to avoid this problem i.e. the introduction of the fluorine at an earlier stage. In fact, the synthesis of an intermediate containing a fluorine could be of value for the development of a simple approach to the synthesis of pyrazolo[1,5-a]pyrimidine derivatives and other related heterocycles.

The synthetic scheme started with the synthesis of the 3amino-4-fluoro pyrazole derivative ${ }^{10} \mathbf{6}$ by using fluoro acetonitrile $\mathbf{4}$ as the starting material. An acylation reaction was performed at low temperature with LiHMDS as the base to afford

\footnotetext{
*Tel.: +32 16 337387; fax: +32 16 337340; E-mail address: piet.herdewijn@ @rega.kuleuven.be
} 
the intermediate $\alpha$-fluoro- $\beta$-ketonitrile 5 which was used without further purification in the next step.

The hydrazinolysis of 5 in ethanol to obtain the 3-amino-4fluoro pyrazole 6 is straightforward. The formation ${ }^{11}$ of the 3 fluoro pyrazolo[1,5-a]pyrimidine scaffold was realized by condensation of 6 with diethyl ethoxymethylenemalonate in acetic acid at $100^{\circ} \mathrm{C}$ for $10 \mathrm{~h}$ to afford the pyrazolo[1,5a]pyrimidine 7 in good yield, which after saponification with sodium hydroxide gave 8. A final decarboxylation with Dowtherm A at $230^{\circ} \mathrm{C}$ for $5 \mathrm{~h}$, led to the desired intermediate $\mathbf{9}^{12}$ ${ }^{13}$ (Scheme 2).
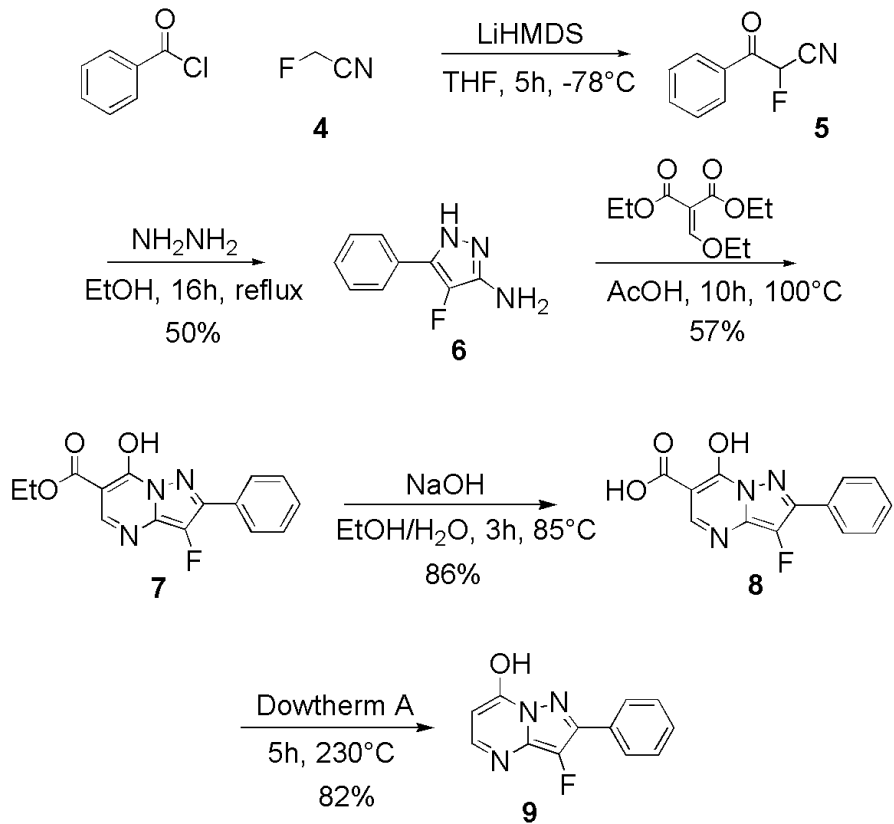

Scheme 2. Synthesis of 3-fluoro-7-hydroxy-2-phenyl pyrazolo[1,5a]pyrimidine.

Intermediate $\mathbf{9}$ was treated in refluxing phosphorus oxychloride to give the chlorinated derivative $\mathbf{1 0}$ which was subjected to nucleophilic substitution with different amines to obtain compound $\mathbf{1 1}^{14}$ (Scheme 3). The versatility of this approach was demonstrated by the synthesis of a small-size library as shown in table 1.

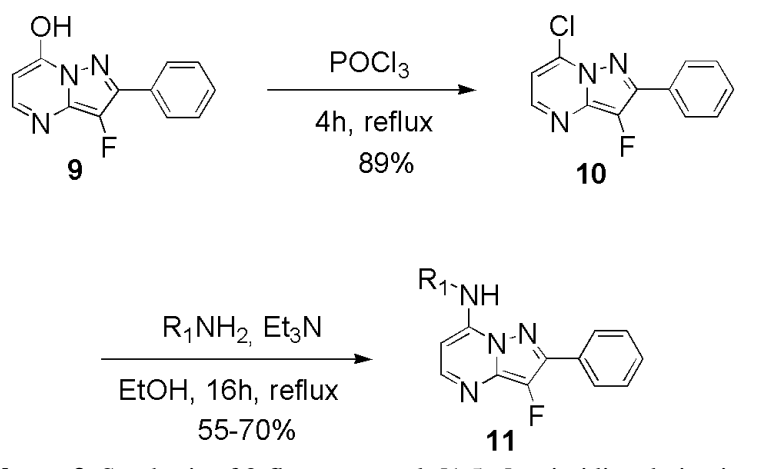

Scheme 3. Synthesis of 3-fluoro pyrazolo[1,5-a]pyrimidine derivatives

The amines used during the last step varied from aliphatic amines, cycloalkyl amines, benzyl amines to heteroaryl amines. The 3-amino-4-fluoro pyrazole 6 has also been condensed with (hetero)aryl dimethylamino propenone $\mathbf{1 3}$ (obtained from acetophenone derivatives 12) in refluxing acetic acid to obtain 3 fluoro-7-(hetero)aryl-2-phenyl-pyrazolo[1,5-a]pyrimidine derivatives $\mathbf{1 4}^{15}$ (Scheme 4).
Table 1. Synthesis of 3-fluoro pyrazolo[1,5-a]pyrimidine derivatives 11 and 14.

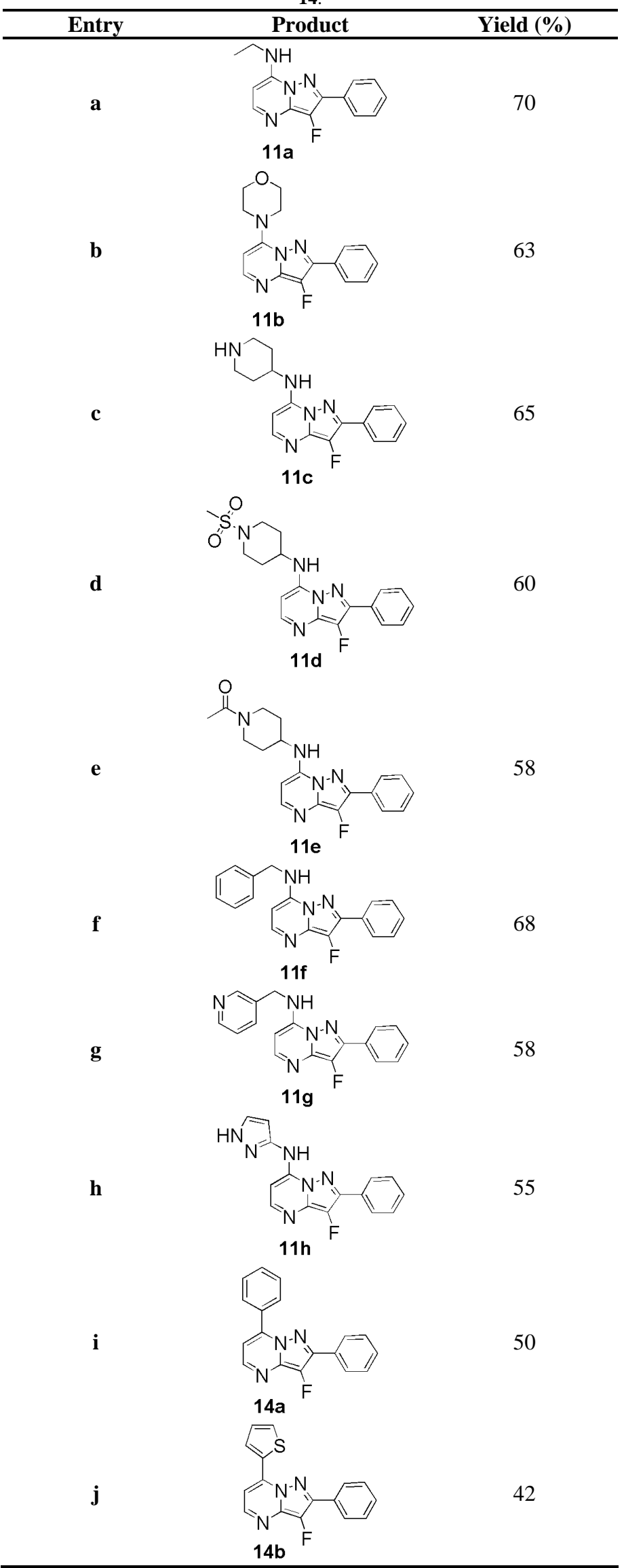




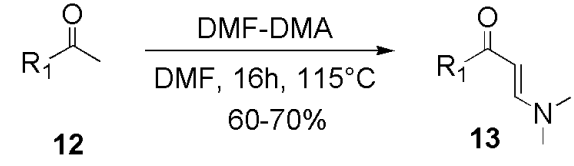

$\mathrm{R}_{1}=$ phenyl, 2-thienyl

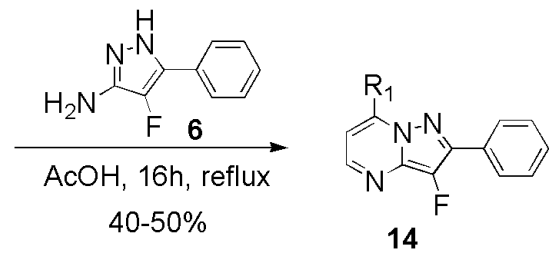

Scheme 4. Synthesis of 3-fluoro-7-(hetero)aryl-2-phenyl pyrazolo[1,5a]pyrimidine derivatives.

In conclusion, we have elaborated a simple approach for the synthesis of 3-fluoro pyrazolo[1,5-a]pyrimidine derivatives by introducing the fluorine at an earlier stage of the synthesis instead of using a direct electrophilic fluorination on the pyrazolo[1,5a]pyrimidine. The method could be employed to the development of a small-size library of "drug-like" compounds with different amines. In a first screening assay, compound $\mathbf{1 1 h}$ showed $71 \%$ of inhibition at $10 \mu \mathrm{M}$ towards the TGF- $\beta$ receptor II. The further biological evaluation of the fluorinated pyrazolo[1,5a]pyrimidines obtained in these experiments is ongoing.

\section{Acknowledgements}

Hassen Bel Abed is indebted to the IWT (Agentschap voor Innovatie door Wetenschap en Technologie) and the Galapagos company for providing a PhD-scholarship (Baekeland-project 90704). He is also grateful to Dr. Karim and Dr. Kachare for their kind suggestions.

\section{References and notes}

1. (a) Gregg, B. T.; Tymoshenko, D. O.; Razzano, D. A.; Johnson, M. R. J. Comb. Chem. 2007, 9, 507-512. (b) Kiessling, A.; Wiesinger, R.; Sperl, B.; Berg, T. ChemMedChem 2007, 2, 627-630. (c) Selleri, S.; Bruni, F.; Costagli, C.; Costanzo, A.; Guerrini, G.; Ciciani, G.; Gratteri, P.; Besnard, F.; Costa, B.; Montali, M.; Martini, C.; Fohlin, J.; De Siena, G.; Aiello, P. A. J. Med. Chem. 2005, 48, 6756-6760. (d) Mason, J. S.; Morize, I.; Menard, P. R.; Cheney, D. L.; Hulme, C.; Labaudiniere, R. F. J. Med. Chem. 1995, 42, 3251-3264.

2. Berger, D. M.; Torres, N.; Dutia, M.; Powell, D.; Ciszewski, G.; Gopalsamy, A.; Levin, J. L.; Kim, K.; Xu, W.; Wilhelm, J.; Hu, Y.; Collins, K.; Feldberg, L.; Kim, S.; Frommer, E.; Wojciechowicz, D.; Mallon, R. Bio. Med. Chem. Lett. 2009, 19, 6519-6523.

3. Williamson, D. S.; Parratt, M. J.; Bower, J. F.; Moore, J. D.; Richardson, C. M.; Dokurno, P.; Cansfield, A. D.; Francis, G. L.; Hebdon, R. J.; Howes, R.; Jackson, P. S.; Lockie, A. M.; Murray, J. B.; Nunns, C. L.; Powles, J.; Robertson, A.; Surgenor, A. E.; Torrance, C. J. Bio. Med. Chem. Lett. 2005, 15, 863-867.

4. Ren, L.; Laird, E. R.; Buckmelter, A. J.; Dinkel, V.; Gloor, S. L.; Grina, J.; Newhouse, B.; Rasor, K.; Hastings, G.; Gradl, S. N.; Rudolph, J. Bio. Med. Chem. Lett. 2012, 22, 1165-1168.

5. Kosugi, T.; Mitchell, D. R.; Fujino, A.; Imai, M.; Kambe, M.; Kobayashi, S.; Makino, H.; Matsueda, Y.; Oue, Y.; Komatsu, K.; Imaizumi, K.; Sakai, Y.; Sugiura, S.; Takenouchi, O.; Unoki, G.; Yamakoshi, Y.; Cunliffe, V.; Frearson, J.; Gordon, R.; Harris, C. J.; Kalloo-Hosein, H.; Le, J.; Patel, G.; Simpson, D. J.; Sherborne, B.; Thomas, P. S.; Suzuki, N.; Takimoto-Kamimura, M.; Kataoka, K. J. Med. Chem. 2012, 55, 6700-6715.

6. Bel Abed, H.; Mammoliti, O.; Van Lommen, G.; Herdewijn, P. Tetrahedron Lett. 2012, 53, 6489-6491.

7. Kataoka, K.; Suzuki, N.; Kosugi, T.; Imai, M.; Makino, H. Patent WO2004/076458.

8. (a) Nolte, B.; Sucholeiki, I.; Feuerstein, T.; Gallagher, B. M.; Wu, X. Patent WO2008/063671. (b) Dressen, D.; Garofalo, A. W.; Hawkinson, J.; Hom, D.; Jagodzinski, J.; Marugg, J. L.; Neitzel, L. M.; Pleiss, M. A.; Szoke, B.; Tung, J. S.; Wone, D. W. G.; Wu, J.; Zhang, H. J. Med. Chem. 2007, 50, 5161-5167.

9. Krasovsky, L. A.; Hartulyari, A. S.; Nenajdenko, V. G.; Balenkova, E. S. Synthesis 2002, 1, 133-137.
10. Cocconcelli, G.; Ghiron, C.; Haydar, S.; Micco, I.; Zanaletti, R. Synth. Commun. 2010, 40, 2547-2555.

11. (a) Nagahara, K.; Kawano, H.; Sasaoka, S.; Ukawa, C.; Hirama, T.; Takada, A. J. Heterocycl. Chem. 1994, 31, 239-243. (b) Gavrin, L. K.; Lee, A.; Provencher, B. A.; Massefski, W. W.; Huhn, S. D.; Ciszewski, G. M.; Cole, D. C.; McKew, J. C. J. Org. Chem. 2007, 72, 1043-1046.

12. Representative procedure for 6: A $1 \mathrm{M}$ solution of LiHMDS in THF (29.4 mL, $29.4 \mathrm{mmol}, 2.0$ equiv) was added dropwise to a solution of benzoyl chloride $(1.7 \mathrm{~mL}, 14.68 \mathrm{mmol}, \quad 1.0$ equiv $)$ and fluoroacetonitrile $4(0.82 \mathrm{~mL}, 14.68 \mathrm{mmol}, 1.0$ equiv) in dry THF (15 $\mathrm{mL}$ ) cooled to $-78{ }^{\circ} \mathrm{C}$ under nitrogen. The mixture was allowed to reach room temperature after $5 \mathrm{~h}$ of reaction and quenched with a saturated solution of ammonium chloride. The mixture was concentrated under reduced pressure to afford the desired $\alpha$-fluoro- $\beta$ ketonitrile 5 in a form pure enough for the next step.

Hydrazine hydrate ( $64 \%$ in water) $(1.4 \mathrm{~mL}, 29.4 \mathrm{mmol}, 2.0$ equiv) was added to a solution of the $\alpha$-fluoro- $\beta$-ketonitrile $5(14.68 \mathrm{mmol})$ in ethanol $(20 \mathrm{~mL})$, and the reaction was heated at reflux for $18 \mathrm{~h}$. The reaction mixture was allowed to cool to room temperature, and the solvent was evaporated under reduced pressure. The residue was dissolved in dichloromethane and washed with water. The organic phase was concentrated to give a crude product, flash column chromatography on silica gel (ethyl acetate/hexane 90:10) afforded the desired product 6 as a beige powder $(1.3 \mathrm{~g}, 50 \%) ; \mathrm{mp} 115-118^{\circ} \mathrm{C} ;{ }^{1} \mathrm{H}$ NMR (500 MHz, DMSO-d 6 ): $\delta 11.92$ (br. s, $1 \mathrm{H}), 7.66(\mathrm{~d}, J=7.5 \mathrm{~Hz}$, $2 \mathrm{H}), 7.45$ (t, $J=7.4 \mathrm{~Hz}, 2 \mathrm{H}$ ), 7.32 (t, $J=7.3 \mathrm{~Hz}, 1 \mathrm{H}), 4.77$ (br. s, $2 \mathrm{H}$ ); ${ }^{13} \mathrm{C}$ NMR (125 MHz, DMSO- $\left.\mathrm{d}_{6}\right): \delta 143.3,135.9,134.3,129.0,127.9$, 126.2, 124.7. ${ }^{19} \mathrm{~F}$ NMR $\left(470 \mathrm{MHz}\right.$, DMSO- $\left.\mathrm{d}_{6}\right): \delta-186.5$. HRMS calcd for $\mathrm{C}_{9} \mathrm{H}_{8} \mathrm{FN}_{3}(\mathrm{M}+\mathrm{H})^{+}:$: 178.0775 , found: 178.0778 .

13. Representative procedure for 9: To the carboxylic acid $8(1 \mathrm{~g}, 3.66$ mmol) was added Dowtherm A $(10 \mathrm{~mL})$. The suspension was heated to $230{ }^{\circ} \mathrm{C}$ for $5 \mathrm{~h}$. The reaction mixture was cooled to room temperature, then diluted with hexanes $(30 \mathrm{~mL})$, stirred vigorously, filtered, and dried to obtain the desired product 9 as a light brown powder $(0.68 \mathrm{~g}$, $82 \%$ ); mp 205-208 ${ }^{\circ} \mathrm{C} ;{ }^{1} \mathrm{H}$ NMR (500 MHz, DMSO-d 6 ): $\delta 7.97$ (d, $J=$ $7.6 \mathrm{~Hz}, 2 \mathrm{H}), 7.75(\mathrm{~d}, J=5.9 \mathrm{~Hz}, 1 \mathrm{H}), 7.49(\mathrm{t}, J=7.6 \mathrm{~Hz}, 2 \mathrm{H}), 7.39(\mathrm{t}$, $J=7.5 \mathrm{~Hz}, 1 \mathrm{H}), 5.48(\mathrm{~d}, J=5.9 \mathrm{~Hz}, 1 \mathrm{H}) ;{ }^{13} \mathrm{C}$ NMR $(125 \mathrm{MHz}$, DMSO- $\mathrm{d}_{6}$ ): $\delta 157.2,148.0,136.9,131.8,131.7,128.8,128.3,126.5$, 92.8. HRMS calcd for $\mathrm{C}_{12} \mathrm{H}_{8} \mathrm{FN}_{3} \mathrm{O}(\mathrm{M}+\mathrm{H})^{+}$: 230.0724, found: 230.0725 .

14. Representative procedure for 11a: To a solution of $\mathbf{1 0}(100 \mathrm{mg}, 0.4$ mmol, 1.0 equiv) in ethanol $(10 \mathrm{~mL})$ was added a solution of $70 \%$ ethylamine ( $70 \%$ in water) $(48 \mu \mathrm{L}, 0.6 \mathrm{mmol}, 1.5$ equiv), followed by triethylamine $(83 \mu \mathrm{L}, 0.6 \mathrm{mmol}, 1.5$ equiv) at room temperature. The reaction mixture was refluxed for $16 \mathrm{~h}$ and after completion of the reaction (TLC), the reaction mixture was allowed to cool to room temperature. Dichloromethane was added and the organic phase was then washed two times with a saturated solution of $\mathrm{NaHCO}_{3}$, and one time with brine. It was then dried over $\mathrm{Na}_{2} \mathrm{SO}_{4}$, and concentrated in vacuo. Flash column chromatography on silica gel (ethyl acetate/hexane $75: 25$ ) afforded the desired product 11a as a white powder $(72 \mathrm{mg}, 70 \%) ; \mathrm{mp} 212-216^{\circ} \mathrm{C} ;{ }^{1} \mathrm{H}$ NMR $(500 \mathrm{MHz}$, DMSO$\left.\mathrm{d}_{6}\right): \delta 8.16(\mathrm{~d}, J=5.3 \mathrm{~Hz}, 1 \mathrm{H}), 8.13(\mathrm{t}, J=5.8 \mathrm{~Hz}, 1 \mathrm{H}), 8.04(\mathrm{~d}, J=7.3$ $\mathrm{Hz}, 2 \mathrm{H}), 7.55(\mathrm{t}, J=7.6 \mathrm{~Hz}, 2 \mathrm{H}), 7.47(\mathrm{t}, J=7.5 \mathrm{~Hz}, 1 \mathrm{H}), 6.22(\mathrm{~d}, J=$ $5.3 \mathrm{~Hz}, 1 \mathrm{H}), 3.48(\mathrm{~m}, 2 \mathrm{H}), 1.26(\mathrm{t}, J=7.3 \mathrm{~Hz}, 3 \mathrm{H}) ;{ }^{13} \mathrm{C}$ NMR $(125$ MHz, DMSO- $\left.\mathrm{d}_{6}\right): \delta 149.8,146.0,138.7,136.9,135.1,133.5,130.6$, 129.1, 126.7, 85.5, 36.6, 14.2. HRMS calcd for $\mathrm{C}_{14} \mathrm{H}_{13} \mathrm{FN}_{4}(\mathrm{M}+\mathrm{H})^{+}$: 257.1197, found: 257.1195

15. Representative procedure for $\mathbf{1 4 b}$ : To a solution of 3-amino-4-fluoro pyrazole $6(150 \mathrm{mg}, 0.85 \mathrm{mmol}, 1$ equiv) in acetic acid $(5 \mathrm{~mL})$ at room temperature was added 2-thienyl dimethylamino propenone $(170 \mathrm{mg}$, $0.94 \mathrm{mmol}, 1.1$ equiv). The mixture was refluxed for $16 \mathrm{~h}$. The suspension was filtered warm, then washed several times with ethanol and dried to obtain the desired product $\mathbf{1 4 b}$ as a yellow powder (105 $\mathrm{mg}, 42 \%)$; $\mathrm{mp} 233-237^{\circ} \mathrm{C} ;{ }^{1} \mathrm{H}$ NMR (500 MHz, DMSO-d $\left.\mathrm{d}_{6}\right): \delta 8.61(\mathrm{~d}$, $J=4.6 \mathrm{~Hz}, 1 \mathrm{H}), 8.59(\mathrm{~d}, J=3.8 \mathrm{~Hz}, 1 \mathrm{H}), 8.18(\mathrm{~d}, J=5.0 \mathrm{~Hz}, 1 \mathrm{H}), 8.13$ $(\mathrm{d}, J=7.7 \mathrm{~Hz}, 2 \mathrm{H}), 7.82(\mathrm{~d}, J=4.6 \mathrm{~Hz}, 1 \mathrm{H}), 7.62(\mathrm{t}, J=7.7 \mathrm{~Hz}, 2 \mathrm{H})$, $7.52(\mathrm{t}, J=7.5 \mathrm{~Hz}, 1 \mathrm{H}), 7.43(\mathrm{t}, J=4.8 \mathrm{~Hz}, 1 \mathrm{H}) ;{ }^{13} \mathrm{C} \mathrm{NMR}(125 \mathrm{MHz}$, DMSO-d $\left.\mathrm{d}_{6}\right): \delta 149.0,139.2,138.6,136.2,135.0,134.2,132.5,130.0$, 129.6, 129.3, 129.2, 127.8, 126.6, 104.6. HRMS calcd for $\mathrm{C}_{16} \mathrm{H}_{10} \mathrm{FN}_{3} \mathrm{~S}$ $(\mathrm{M}+\mathrm{H})^{+}: 296.0652$, found: 296.0659 . 
Graphical abstract- Simple approach to the synthesis of 3-fluoro pyrazolo[1,5-a]pyrimidine analogues.

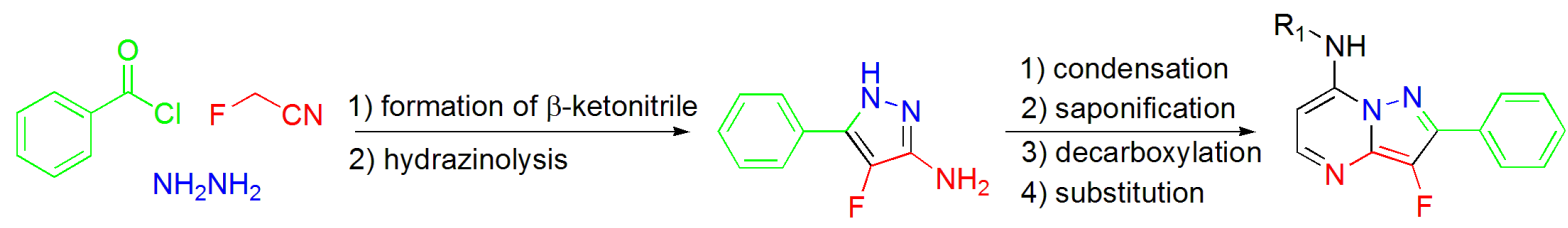

$\mathrm{R}_{1}=$ aliphatic amine, cycloalkyl amine, benzyl amine and heteroaryl amine

Figure 1. Kinase inhibitors based on pyrazolo[1,5-a]pyrimidine.

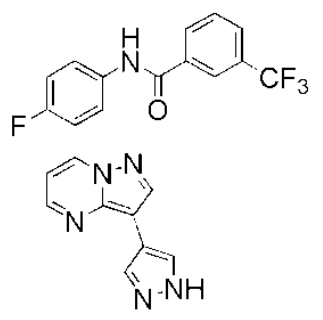

1

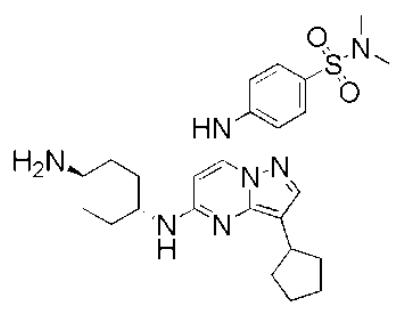

2

Scheme 1. Electrophilic fluorination of the 7-chloro pyrazolo[1,5-a]pyrimidine.

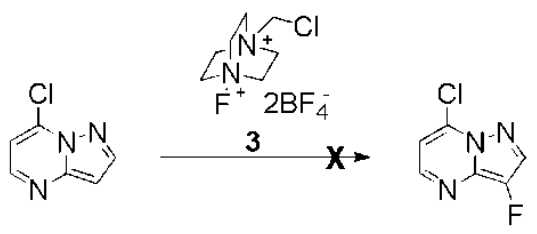

Scheme 2. Synthesis of 3-fluoro-7-hydroxy-2-phenyl pyrazolo[1,5-a]pyrimidine.
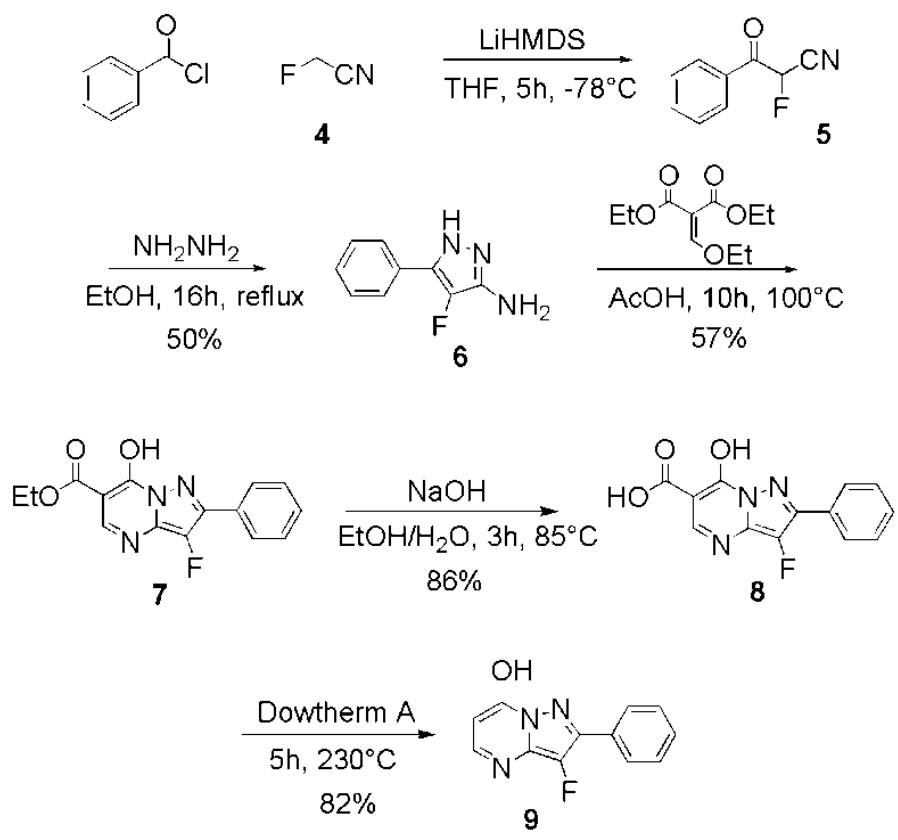
Scheme 3. Synthesis of 3-fluoro pyrazolo[1,5-a]pyrimidine derivatives.

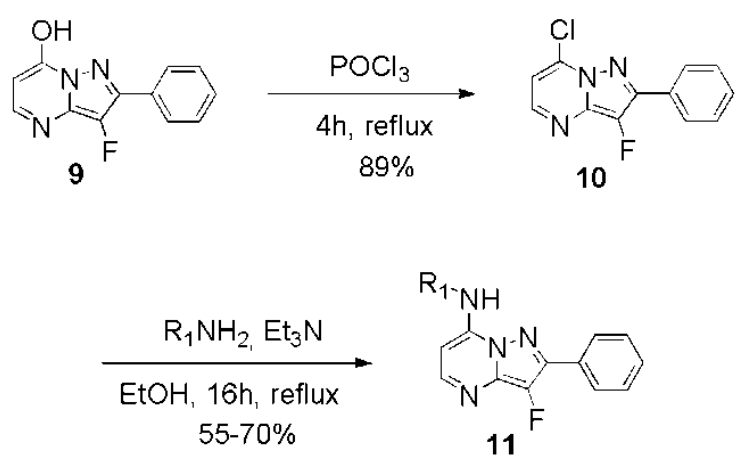

Scheme 4. Synthesis of 3-fluoro-7-(hetero)aryl-2-phenyl pyrazolo[1,5-a]pyrimidine derivatives.

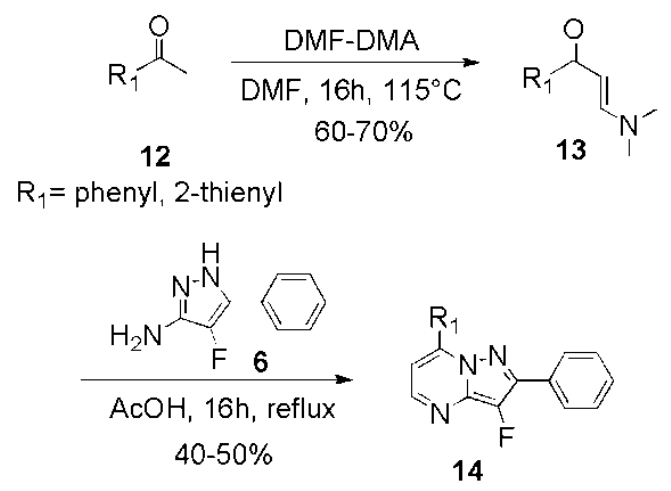

